\title{
Iztok KOVAČIČ
}

\section{Arhitekturna dimenzija dela na daljavo}

Računalnik je sestavni del bivalnega okolja. Z uvedbo moderne informacijske in komunikacijske tehnologije znotraj delovnih procesov se spreminja organizacija pisarniškega dela, kar vpliva na potrebne prostore ter posledično na zasnovo poslovnih zgradb. Neodvisnost, ki jo prinaša razvoj vedno novih, vedno bolj izdelanih, sofisticiranih in mobilnih pridobitev informacijske in komunikacijske revolucije, omogoča poleg dela v pisarni tudi delo na domu, v vlaku, hotelu ali celo na plaži, travniku, v parku. Poimenujemo ga delo na daljavo. Ena od novejših različic tega tipa prinaša kombinacijo dela $\checkmark$ pisarni in na domu. Gre za koncept deljene pisarne, kjer zaposleni večino samostojnega dela opravijo doma, medtem ko se v pisarno odpravljajo zgolj za sestanke, posvete in druge oblike skupinskega dela. Pisarniška poslopja prihodnosti bodo zato v prvi vrsti namenjena delovnim procesom, pri katerih bosta potrebna skupno delovanje in usklajevanje, kar naj bi utrjevalo medsebojno zaupanje in občutek za skupnost. To bodo kraji spoznavanja in komuniciranja, kjer se ljudje srečujejo in izmenjujejo svoja mnenja. Arhitektura tako dobiva katalitično funkcijo povezovanja.
The computer has become an integral part of our environment. With the integration of information and communication technologies into the working process the organization of office work is rapidly changing, influencing the office spaces as well as office buildings. The continuous evolution of sophisticated and mobile devices, developed as a result of information and communication revolution, enables us not only to work in the office but also at home, on the train, in hotels or even on the beach, in the park. The common name for this kind of activity is teleworking. One of the latest varieties is the combination of mobile work and home office that was called Sharing office. The workers usually perform most of their tasks at home and only come to office for briefings, meetings or similar kind of operation. The office building of the future will therefore be created with the purpose to connect and unite workers for common tasks and reconciliation. It will become the center point for people to meet and communicate. Architecture will therefore take upon itself the catalyst function.

\author{
Arhitektura \\ Deljena pisarna \\ Delo na daljavo \\ Delovni tipi \\ Pisarna \\ prihodnosti \\ Računalnik \\ Architecture \\ Computer \\ Future office \\ Sharing office \\ Teleworking \\ Work types
}

\section{Računalnik kot generator sprememb}

Računalnik je postal sestavni del bivalnega okolja. $Z$ uvedbo moderne informacijske in komunikacijske tehnologije znotraj delovnih procesov se spreminja organizacija pisarniškega dela, kar vpliva na potrebne prostore ter posledično na zasnovo poslovnih zgradb. Vse to se izraža tudi v podobi mesta. Obstajajo celo napovedi, da naj bi se mesto zaradi tehnične revolucije ne samo preobrazilo, temveč tudi razkrojilo. Kot je trdil W. J. Mitchell, naj bi mu elektronska mreža prevzela njegovo primarno funkcijo, to je komunikacijo. (1996) Omrežje bo postalo nova urbana struktura. Znotraj mestnega prostora se bodo poglabljale razlike med velikimi javnimi in komercialnimi poslopji ter stanovanjskimi predeli. Značilne lokacije, ki določajo mesto, bodo doživele razkroj, tudi zaradi opuščanja vsakdanjih aktivnosti, kot so odhajanje na delo, nakupovanje, bivanje. Človek-sprehajalec bo izginil iz mestnega prostora, njegov edini stik $\mathrm{z}$ jedrom bo prek računalniške tipkovnice. Dnevni utrip mesta se bo izgubil v 24-urnem kaosu, računalnik bo $\mathrm{v}$ jedru dogajanja.

V nasprotju s tem Kohlbrenner trdi, da se bo zaradi pojava računalnika in $\mathrm{s}$ tem povezanih pridobitev tehnološkega napredka mesto sicer spremenilo, vendar pa se bo njegov sistem ohranil (1999: 169). Znotraj tega sistema se bodo odvijali procesi, ki zajemajo spremembe delovnih in bivalnih prostorov mesta ter ga tako preoblikujejo. Pri tem je značilno, da se mesto odziva zelo počasi, medtem ko se delovni procesi v navezavi na najmodernejšo tehnologijo zelo hitro spreminjajo. Razlika je torej v hitrosti prilagajanja. Z novimi možnostmi konceptov delovnih mest, med katere spada v zadnjem obdobju tudi delo na daljavo, se mestni prostor preoblikuje in spreminja.

Vsak izmed pisarniških delovnih konceptov vpliva na prostor prek treh ravni. To so: ožji delovni prostor (pisarna), pisarniško poslopje 
in mestni prostor oziroma mesto samo. Če se ožji delovni prostor s svojo notranjo opremo precej hitro prilagaja novim delovnim konceptom, pa je že poslopje po svoji strukturi veliko bolj togo in mora biti primerno za uporabo vsaj nekaj deset let. Pri mestu gre še za daljše časovno obdobje, ko naj bi funkcioniralo ne glede na vse spremembe znotraj njega samega.

Današnji vplivi informacijske in komunikacijske družbe preoblikujejo življenjski in delovni prostor povsem drugače in $z$ nepredstavljivo hitrostjo. $Z$ razvojem informacijskih in komunikacijskih tehnologij se pred našimi očmi spreminja tudi pojmovanje dela in delovnega časa. (Lippert, 1997) Nič več ne gre zgolj za navzočnost na določenem kraju in ob določenem času, temveč je pomembnejša učinkovitost $\mathrm{v}$ določenem časovnem obdobju. Prostor in čas tako $\mathrm{v}$ povezavi $\mathrm{z}$ delovnim konceptom dobivata popolnoma nove dimenzije. $\mathrm{Za}$ načrtovanje dela in delovnih mest $\mathrm{v}$ prihodnosti moramo razjasniti bistvena vprašanja: kako pomembna bo fizična navzočnost delavca $v$ podjetju in delovnem procesu? Kako je mogoče z oblikovanjem prostora spodbuditi delavce in kako prilagoditi delovno orodje za učinkovito in motivirano delo? In končno, kako naj se delovni koncepti prilagajajo neprenehnemu tehnološkemu napredku, ob tem pa ostanejo zahteve človeka na prvem mestu?

\section{Osnovni delovni tipi}

Ena od posledic razvoja informacijskih tehnologij je tudi vse večja specializacija, ki še veča pomen skupinskega dela, v katerem se združujejo strokovnjaki $\mathrm{z}$ različnih področij za sodelovanje v kompleksnih projektih. Dosedanja delitev dela, ki je razporejala osebje, npr. $v$ vodjo, tajnico, referenta, se spreminja $v$ integrirano delovno skupino, znotraj katere se vsak posameznik sam odloča, kdaj in kako bo delal oziroma kako in kje bo delal sam. Glede na to lahko vse delujoče razvrstimo v tri osnovne tipe (Ehlers in sod., 2003, str. 111-112):

- Tradicionalni delovni tip - gre za tipično delovno mesto posameznika, ki prebije pretežni del dneva $\mathrm{v}$ pisarni in svoje delo opravlja tako, da komunicira s sodelavci, organizira delo drugih ljudi, daje naloge, jih nadzira in bedi nad integralnim funkcioniranjem enega delovnega proce- sa. Za ustvarjalni del svojega dela utegne potrebovati zasebnost, tišino ter vizualno in telesno udobje, čeprav gre $\mathrm{v}$ glavnem za rutinsko delo;

- Mobilni delovni tip - pri takšnem delu posameznik pretežno potuje, obiskuje stranke in dela skorajda vsepovsod (sejmi, konferenčne dvorane, hotelske sobe, letala ...), ob tem pa uporablja vrhunsko tehnologijo (notesnike, mobilne telefone, osebne digitalne organizatorje) ter se redno po elektronski pošti ali telefonu povezuje s svojo matično enoto;

- Delavec v domačem okolju je tip delavca, ki dela pretežno oziroma izključno doma in ki je temu ustrezno tudi fizično ločen od drugih članov družine ter ustvarja v domačem, svojim potrebam primerno oblikovanem delovnem okolju. Ob tem uporablja vso tehnološko opremo, ki je na voljo v danem časovnem okvirju, ter po sodobnih elektronskih poteh komunicira s preostalim delom svoje osnovne skupine.

Če za prvi tip še vedno velja, da je pri svojem delu vezan na pisarniške prostore, kot jih poznamo v klasičnem pomenu, pa lahko za oba slednja trdimo, da ju je omogočil šele razvoj računalniške tehnologije.

\section{Delo na daljavo}

Neodvisnost, ki jo prinaša razvoj vedno novih, vedno bolj izdelanih, sofisticiranih in mobilnih pridobitev informacijske in komunikacijske revolucije, omogoča poleg dela v pisarni tudi delo na domu, v vlaku, hotelu ali celo na plaži, travniku, v parku ... Z zvenečimi imeni, kot so: desk-sharing, non-territorial office,telework, hotteling, satellite office in home-office, se poskušajo uveljaviti novi koncepti dela, ki lahko ob dokazanih časovnih in prostorskih prednostih ter ugodnih razmerah nadomestijo tradicionalno samostojno delovno mesto. S skupnim imenom jih označimo kar delo na daljavo. 
Eden od poglavitnih argumentov za uvedbo dela na daljavo je racionalizacija delovnih mest. Že pri tradicionalnih oblikah dela je znotraj normalnega delovnika $\mathrm{v}$ povprečju sočasno zasedenih le maksimalno 70 odstotkov delovnih mest. Zaradi izostankov zaradi bolezni, dopustov, obiskovanja strank, izobraževanja in raznih drugih oblik odsotnosti je izkoristek še mnogo manjši. Poleg tega se večina dela $v$ pisarnah še vedno opravlja podnevi, medtem ko so ponoči nezasedene. Ker so stroški vzdrževanja pisarniške opreme po velikosti takoj na drugem mestu za stroški delovne sile, se število samostojnih delovnih mest $\mathrm{v}$ pisarniških poslopjih krepko zmanjšuje, individualne delovne površine z osebnimi predmeti pa bodo prej izjema kot pravilo. Stroga časovna delitev dela in delo v izmenah bosta uporabna samo še $\mathrm{v}$ industrijskih halah. V nasprotju s tem se pisarniško delo oddaljuje od strogo odmerjenega delovnega časa. Le tako bo namreč mogoče ohranjati stike s partnerji po svetu ter usklajevati globalne aktivnosti, saj se delovni čas zaradi različnih časovnih pasov večinoma le redko prekriva.

Z globalizacijo se veča razdrobljenost delovnega časa, veča pa se tudi uporaba pisarn za skupinske naloge, sestanke, skupinsko delo, izmenjavo mnenj itd. Pisarniške stavbe, ki so bile $v$ preteklosti središča za individualno delo, s poudarkom na samostojnih delovnih mestih, se čedalje bolj nagibajo $\mathrm{k}$ funkcijam komunikacije in združevanja. Delovni prostor pisarne je že od nekdaj prostor, kjer je komunikacija bistvenega pomena za delo. Takšen status ima že vse od iznajdbe telefona pa tja do prihoda računalnika in razvoja telekomunikacij. Računalnik v povezavi s telefonom je postal integralni del vsakega komunikacijskega sistema sodobne pisarne. Kadar človek komunicira z drugimi ljudmi zgolj prek omejenega sistema in nima nobenih stikov z njimi, velja, da je popolnoma vseeno, kje je. Takšna premisa je osnova za delo na daljavo. Spoznanje, da ni več pravega razloga, da bi se ljudje zaradi dela zbirali na istem kraju in ob istem času, do temeljev podira ukoreninjene predstave o tradicionalnem načinu dela. Posledice zbiranja zaradi skupnega dela so večplastne in se negativno izražajo na socialnem, ekonomskem in ekološkem področju. Tog in vnaprej določen skupinski delovni čas precej omejuje človekovo časovno neodvisnost, ločene stanovanjske in poslovne stavbe pomenijo visoke stroške in neracionalno izrabo naravnega okolja, vsakodnevne migracije na delo pa pomenijo ogromne transportne stroške.
$\mathrm{Z}$ uvedbo dela na daljavo je mogoče združevati bivanjske in delovne procese, s čimer že v osnovi premostimo najbolj pereče pomanjkljivosti tradicionalnega načina dela. Priložnost, ki jo je omogočil razvoj računalnika in telekomunikacij, so določena podjetja izkoristila že $\mathrm{v}$ začetku devetdesetih let, ko se je omrežje toliko razvilo, da je bilo mogoče nove koncepte dejansko uresničiti. Ob tem so se izkristalizirali štirje poglavitni razlogi, ki govorijo v prid razširitve dela na daljavo:

- kot prvo velja upoštevati racionalizacijo pisarniških prostorov, višjo fleksibilnost dela ter zmanjšanje stroškov pri vzdrževanju pisarn,

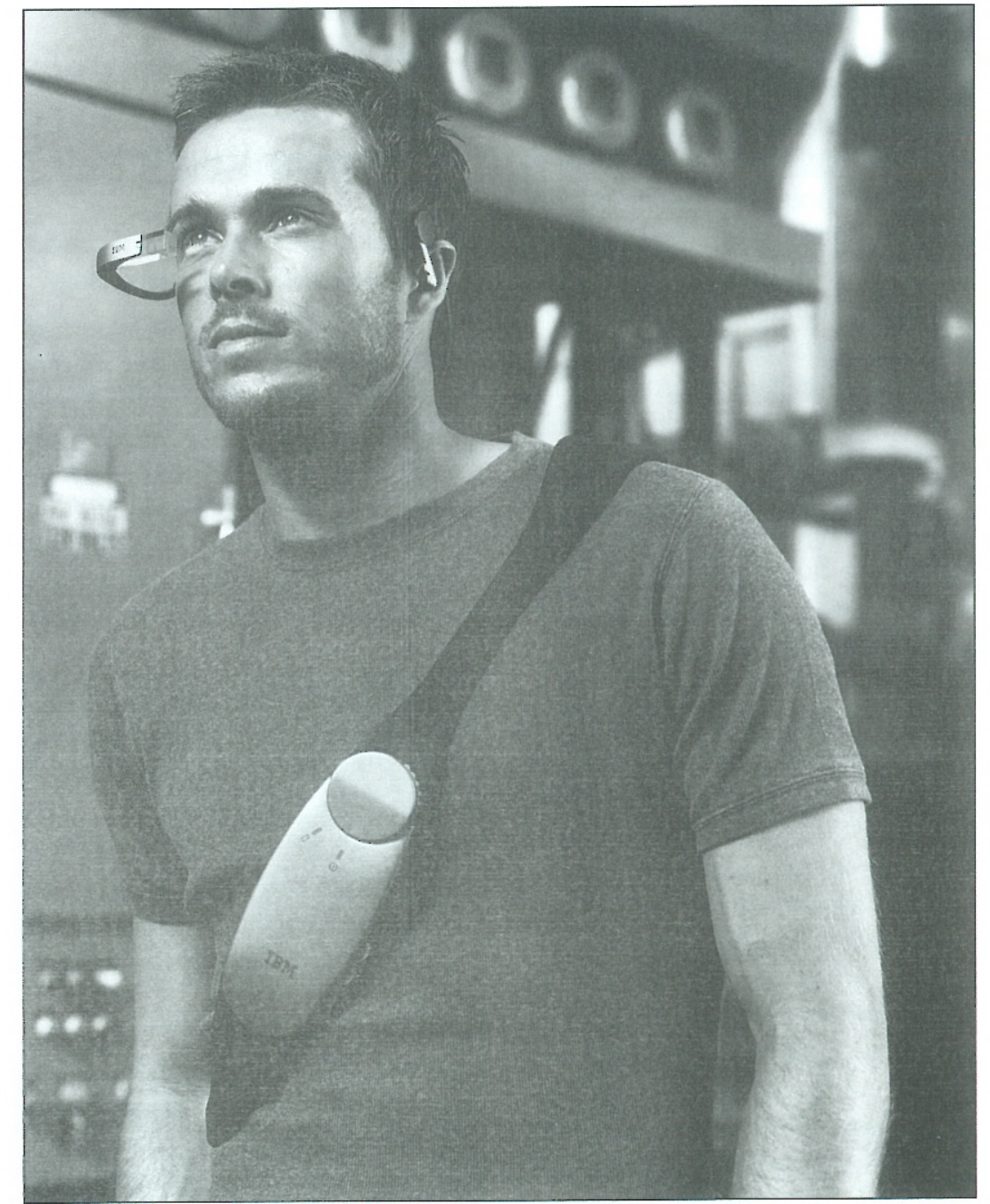

Slika 2: Nosljivi računalnik - Nenehni razvoj prefinjenih in mobilnih računalniških naprav nam omogoča, da lahko delamo skoraj kjerkoli. (Vir: http://www.ibm.com) 
- še bolj se zvišuje produktivnost delavcev (tako kakovost kot količina $\mathrm{v}$ določenem časovnem obdobju),

- poleg tega so tudi sami zaposleni zaznali prednosti dela na daljavo in ga sprejeli kot zaželeno (oziroma ga celo zahtevajo),

- in ne nazadnje: znižanje dnevne migracije je dobrodošlo tako $\mathrm{z}$ ekonomskega kot ekološkega stališča.

\section{Koncept deljene pisarne}

Med različnimi tipi dela na daljavo sta najpogostejša mobilno delo na terenu in delo na domu. Ena od novejših različic pa predpostavlja kombinacijo dela $\mathrm{v}$ pisarni in na domu. Strokovnjaki so jo poimenovali non-territorial office oziroma desk sharing, kar bi lahko prevedli tudi kot koncept pisarne $z$ delitvijo miz. V nasprotju z drugimi tipi dela, ki se med sabo ločujejo glede na prostorske kvalitete, ta izhaja iz drugačne organizacije delovnega procesa. Koncept deljene pisarne namreč temelji na opazovanjih, ki so v daljših časovnih obdobjih pokazala, da je zasedenost nekega delovnega mesta v povprečju tako majhna, da bi bilo veliko bolje predvideti takšno delovno okolje, ki bi se sprotno prilagajalo delovnim nalogam.

Tipična značilnost deljene pisarne zato temelji na dejstvu, da zaposleni nimajo svojega stalnega delovnega mesta, temveč se postavitev notranje opreme glede na potrebe vseskozi spreminja. Zaposleni namreč večino samostojnega dela opravijo doma, medtem ko se v pisarno odpravljajo zgolj za sestanke, posvete in druge oblike skupinskega dela. Vsaka pisarna, vsak delovni prostor, miza ali pisarniška oprema so enakovredno na razpolago komurkoli in ob katerikoli uri. Osebne stvari so spravljene v posebnem mobilnem predalniku, ki ga uslužbenec prevzame ob pri- hodu na delo in se nato $\mathrm{z}$ njim pomika po prostoru do poljubnega delovnega mesta. Po opravljenem delu delovno mesto pospravi, osebni predalnik pa zapelje $\mathrm{v}$ posebni, za to predvideni prostor.

Takšna zasnova delovnega prostora in notranje opreme mora biti nujno podprta $\mathrm{z}$ dobro razvito in brezhibno delujočo tehnološko infrastrukturo, ki omogoča pretok informacij in komunikacijo med uporabniki in računalniki na kateremkoli od izbranih delovnih mest. Ker niso nikoli polno zasedena, jih je vse manj (od 50 do 80 odstotkov) glede na število zaposlenih.

\section{Pisarniško poslopje kot središče komunikacije}

Pisarniška poslopja prihodnosti bodo v prvi vrsti namenjena delovnim procesom, pri katerih bosta potrebna skupno delovanje in usklajevanje, kar naj bi utrjevalo medsebojno zaupanje in občutek za skupnost. To bodo kraji spoznavanja in komuniciranja, kjer se ljudje srečujejo in izmenjujejo mnenja. Samostojna delovna mesta $\mathrm{za}$ tradicionalno delo se bodo $\mathrm{v}$ majhnem obsegu sicer še obdržala, pri tem pa zaradi tehnoloških zmožnosti ne bodo več vezana na določen čas in prostor, zato pri načrtovanju prostora ne bodo več $\mathrm{v}$ prvem planu.

$\mathrm{V}$ preteklosti zgrajena pisarniška poslopja so se prilagajala zahtevam tradicionalnih organizacijskih oblik samostojnega dela, ki jih še do danes najbolje utelešajo individualne celične pisarne. Zdajšnje zahteve za pisarniške stavbe in druge podobne prostorske strukture so popolnoma drugačne, saj v ospredje postavljajo skupinsko delo ter stike med ljudmi. Če upoštevamo, da je kakovost človeškega dela danes neposredno odvisna od kakovosti informacijskih procesov in komunikacije znotraj konkretnega delovnega prostora, potem je zagotovitev takšnih prostorov primarna naloga pri načrtovanju pisarniških poslopij prihodnosti.

Razvoj grajenih struktur je lahko zgolj rezultat interakcije med različnimi disciplinami in vejami znanosti. Projekcije za prihodnost so si enotne $\mathrm{v}$ napovedi, da se bodo arhitektom pri projektiranju objektov vse bolj pridruževali računalniški programerji, strojni in elektroinženirji, fiziki, antropologi, ergonomi, oblikovalci, izdelovalci pohištvene opreme, organizatorji dela ter poznavalci

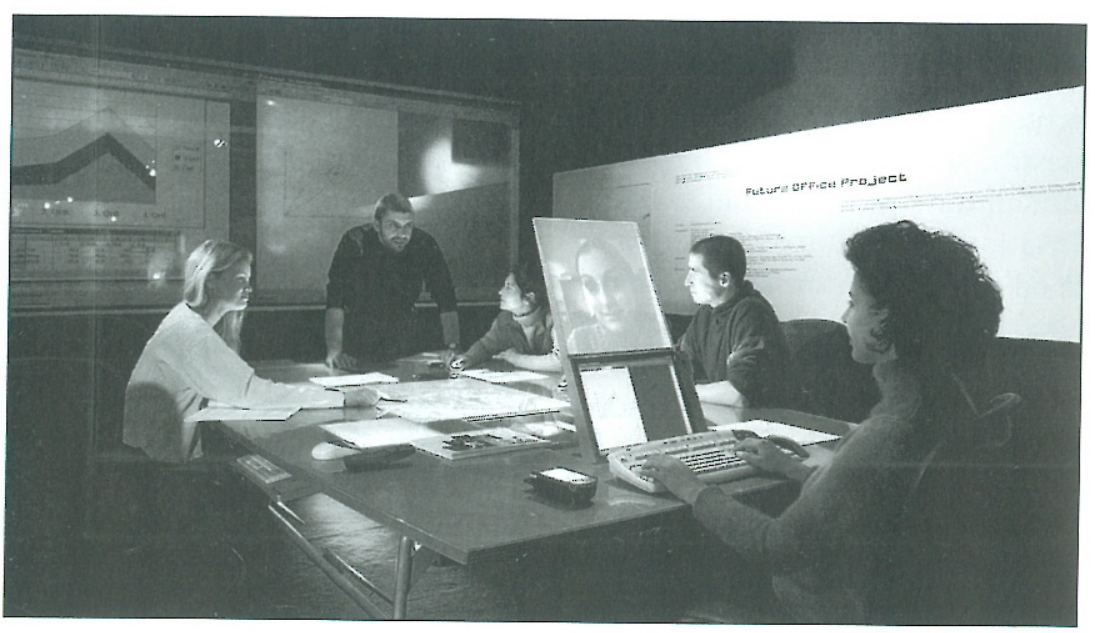

Slika 3: Pisarniška poslopja prihodnosti bodo središča komunikacije, načrtovana, da povezujejo in združujejo ljudi za skupne naloge. (Vir: Stocker, G. 2001: Future office project. http://www.aec.at/en/futurelab/projects) 
spletnih tehnologij. Takšno skupno sodelovanje bo nujno za raziskovanje vseh možnih konceptov delovnega procesa, ki se zaradi nepredstavljivega razvoja informacijskih in komunikacijskih tehnologij vse preveč osredotoča na tehnične zmogljivosti, pri tem pa zanemarja potrebe človeka. V bližnji prihodnosti bo treba prilagoditi računalniški hardver in softver, da se bosta primerno odzivala na povezovanje socialnih in organizacijskih struktur, na nove oblike in metode dela ter na antropološke zahteve, ob tem pa se bosta kar najuspešneje integrirala $\mathrm{v}$ konkretno delovno okolje. Šele ko bo računalniku to uspelo, bo upravičil vlogo za katero je bil narejen: da predvidljivo in zanesljivo pomaga človeku, ne da bi se ga ta sploh zavedal.
Kljub splošni uporabi računalnika in povezanosti ljudi prek podatkovnega in komunikacijskega omrežja ostaja neposredna komunikacija v živo še vedno eden najpomembnejših dejavnikov za zagotavljanje optimalnih rezultatov $\mathrm{v}$ inovativnih in kreativnih delovnih procesih. Tudi načrtovalci se zavedajo zahtev po nenehnem izboljševanju kakovosti dela, zato se nagibajo $\mathrm{k} \mathrm{za-}$ snovam, ki bodo zaposlene spodbujale k čim boljši medsebojni komunikaciji. Arhitektura tako dobiva katalitično funkcijo povezovanja. [Remmers, 1999: 39]

Iztok Kovačič, univ. dipl. inž. arh., mlad raziskovalec, Univerza v Ljubljani,

Fakulteta za arhitekturo, Ljubljana E-pošta: iztok.kovacic@volja.net

\section{Viri in literatura}

Ehlers, I. L, Greisle, A., Hube, G., Kelter, J., Rieck, A. (2003) OFFICE 21 - Crucial Influences on Office Performance, Egmont vgs verlagsgesellschaft $m b H$, Köln.

Guallart, V. (2004) The house is the computer, the structure is the network (Media house project), laac, Barcelona.

Kohlbrenner, U. (1999) Arbeitswelten im Wandel - fit für die Zukunft? - Orte fürs Büro - Orte in der Stadt, Deutsche Verlags Anstalt, Stuttgart.

Lippert, W. (1997) Future office, Metropolitan Verlag (Walhalla Verlagsgruppe), Regensburg

Mitchell, W. J. (1996) City of Bits: Space, Place, and the Infobahn, The MIT Press, Cambridge, Massachusetts.

Remmers, B. (1999) Arbeitswelten im Wandel - fit für die Zukunft? - Vom steinzeitlichen Palaver zur modernen Kommunikationsförderung. Deutsche Verlags Anstalt, Stuttgart.

\section{Breda MIHELIČ}

\section{Geografski informacijski sistem kot orodje $\mathrm{za}$ analizo in vrednotenje stanja $\mathrm{v}$ prostoru ter določanje prioritetnih območij prenove}

\begin{abstract}
Propadanje mestnih središč in izgubljanje njihove stanovanjske funkcije sta najbolj pereča problema evropskih zgodovinskih mest. Rešitev je nedvomno $v$ prenovi degradiranih območij znotraj mestnih središč in izboljšanju kakovosti življenja $v$ njih. Te probleme bi mesta lahko uspešneje reševala, če bi pozorno in kontinuirano spremljala stanje $v$ prostoru in sproti identificirala tista območja, na katerih je potreba po prenovi najnujnejša, in tiste probleme, ki jih je treba najprej reševati. Kot orodje za sistematično spremljanje stanja $v$ prostoru smo na Urbanističnem inštitutu v sklopu več projektov, razvili računalniško podprto metodologijo, ki omogoča evidentiranje in vrednotenje prioritetnih območij prenove.
\end{abstract}

\begin{abstract}
Dilapidation of city centres and their loss of housing functions are the most pending problems of European historical cities. Their solution undoubtedly lies in rehabilitation of degraded areas in city centres and the improvement of quality of life within. These problems could be resolved more successfully if cities carefully and continuously monitored spatial conditions and correspondingly identified areas where rehabilitation is essential, as well as issues that need immediate resolving. Within the framework of several projects undertaken at the Urban planning institute, we developed a computer-aided methodology that enables evidencing and evaluation of prime rehabilitation areas as a tool for systematic monitoring of spatial conditions.
\end{abstract}

\author{
GIS \\ Prenova \\ Ljubljana \\ Mestno središče \\ GIS \\ Rehabilitation \\ Ljubljana \\ City centre
}

\section{Uvod}

Urbanistični inštitut RS je partner v mednarodnem projektu Reurban
Mobil (reurbanisation on the condition of demographic change), ki poteka $v 5$. okvirnem programu EU in se ukvarja s problemom propa- danja in prenove stanovanjskih četrti znotraj mestnih središč. Projekt je bil že v izhodišču zasnovan interdisciplinarno in je $\mathrm{v}$ delovnem 